\title{
Water Treatment Challenges towards Viruses Removal
}

\author{
Djamel Ghernaout ${ }^{1,2}$ \\ ${ }^{1}$ Chemical Engineering Department, College of Engineering, University of Ha'il, Ha'il, KSA \\ ${ }^{2}$ Chemical Engineering Department, Faculty of Engineering, University of Blida, Blida, Algeria \\ Email: djamel_andalus@hotmail.com
}

How to cite this paper: Ghernaout, D. (2020) Water Treatment Challenges towards Viruses Removal. Open Access Library Journal, 7: e6408.

https://doi.org/10.4236/oalib.1106408

Received: May 9, 2020

Accepted: May 22, 2020

Published: May 25, 2020

Copyright $\odot 2020$ by author(s) and Open Access Library Inc.

This work is licensed under the Creative Commons Attribution International License (CC BY 4.0).

http://creativecommons.org/licenses/by/4.0/

(c) (i) Open Access

\begin{abstract}
In spite of the considerable development registered in microbiology, humankind remains incapable to dominate scientifically and technologically the large microbial world. This is well established and illustrated, unfortunately, in the present Coronavirus disease (COVID-19) pandemic. This work aims to contribute to highlighting the world of pathogenic microorganisms, especially viruses, and their removal from potable water. Identical to the manner by which chemical contaminants are handled in the environment, the particular properties that control transport and demobilization of enveloped viruses in solutions, on surfaces, and in the air must be understood. Besides, the fashion by which ecological parameters form likely virus transmission and mutation mechanisms should be comprehended. Since water treatment constitutes a secure barrier against drinking water infection, the main stages in the water treatment plant dealing with pathogens removal such as disinfection have to be enhanced with more efficient techniques such as advanced oxidations processes. In the field of eliminating pathogens, some research trends are suggested especially those founded on thermal destruction and solar irradiation due to their high performance and low costs.
\end{abstract}

\section{Subject Areas}

Chemical Engineering \& Technology, Environmental Chemistry

\section{Keywords}

Pathogenic Microorganisms, Water Treatment, Viruses, Coronaviruses, Disinfection, Drinking Water

\section{Introduction}

Even if persons are constantly revealed to a large range of microorganisms in 
nature, only a small part of such microbes are able of interacting with the host in such a fashion that infection and illness will end in [1] [2] [3]. Disease-causing microorganisms are named pathogens [4] [5] [6]. Infection is the phenomenon by which the microorganism multiplies or grows in or on the host [7] [8] [9]. Infection does not inevitably conduct to illness as it is conceivable for the organism to grow in or on the host without provoking disease [10] [11] [12]. As an example, in the situation of enteric infections (i.e., diarrhea) induced by Salmonella, only half of the persons infected grow symptoms of the disease [13] [14]. An obvious pathogen is a microorganism apt for generating illness in both normal healthy and immunocompromised individuals [15] [16] [17]. Opportunistic pathogens are frequently apt for provoking infections only in immunocompromised persons like burn patients, patients taking antibiotics [18] [19] [20], those with impaired immune systems, or elderly patients with diabetes. Opportunistic pathogens are current in nature and can occur in the human gut or skin without provoking illness [1].

To occasion disease, the pathogen has frequently first to expand inside or on the host. The period from infection to the manifestation of symptoms (diarrhea, fever, rash, etc.) is the incubation time (Table 1). Such time could extend from 6 to $12 \mathrm{hrs}$ in the case of norovirus diarrhea, or up to 30 to 60 days for the hepatitis A virus, which provokes liver disease. At any moment throughout infection, the pathogen may be liberated into nature by the host in feces, urine, or respiratory secretions. Even if the maximum liberation can happen at the highest point of the illness, it may also come before the initial symptoms. In the case of the hepatitis A virus, the maximum excretion in the feces takes place before the onset of signs of clinical disease. The level of organisms liberated into nature changes with the kind of organism and the pathway of transmission (Table 2).

Table 1. Incubation period for usual enteric pathogens [1].

\begin{tabular}{cccc}
\hline Agent & Incubation time & Fashions of transmission & Duration of disease \\
\hline Adenovirus & $8-10$ days & Fecal-oral-respiratory & 8 days \\
Campylobader jejuni & $3-5$ days & Food ingestion, direct contact & $2-10$ days \\
Cryptosporidium & $2-14$ days & Food or water ingestion, direct and indirect contact & Weeks to months \\
Escherichia coli (enterotoxigenic-ETEC) & $16-72 \mathrm{~h}$ & Food or water ingestion & $3-5$ days \\
E. coli (enteropathogenic-EPEC) & $16-48 \mathrm{~h}$ & Food or water ingestion, direct and indirect contact & $5-12$ days \\
E. coli (enterohemorrhagic-EHEC) & $72-120 \mathrm{~h}$ & Food/ingestion, direct or indirect contact & $2-15$ days \\
Giardia lamblia & $7-14$ days & Food or water ingestion, direct and indirect contact & Weeks to months \\
Norovirus & $24-48 \mathrm{~h}$ & Food or water ingestion, direct and indirect contact, aerosol? & $1-2$ days \\
Rotavirus & $24-72 \mathrm{~h}$ & Direct and indirect contact & $4-6$ days \\
Hepatitis A & $30-60$ days & Fecal-oral, fomites & $2-4$ weeks \\
Salmonella & $16-72 \mathrm{~h}$ & Food ingestion, direct and indirect contact & $2-7$ days \\
Shigella & $16-72 \mathrm{~h}$ & Food or water ingestion, direct and indirect contact & $2-7$ days \\
Yersinia enterocolitica & $3-7$ days & Food ingestion, direct contact & $1-3$ weeks \\
\hline
\end{tabular}


Table 2. Concentration of enteric pathogens in feces [1].

\begin{tabular}{cc}
\hline Organism & Per gram of feces \\
\hline Protozoan parasites & $10^{6}-10^{7}$ \\
Helminths & $10^{4}-10^{5}$ \\
Ascaris & \\
Enteric viruses & $10^{3}-10^{7}$ \\
Enteroviruses & $10^{10}$ \\
Rotavirus & $10^{11}$ \\
Adenovirus/Norovirus & \\
Enteric bacteria & $10^{4}-10^{10}$ \\
Salmonella spp. & $10^{5}-10^{9}$ \\
Shigella & \\
Indicator bacteria & $10^{7}-10^{9}$ \\
Coliforms & $10^{6}-10^{9}$ \\
Fecal coliforms & \\
\hline
\end{tabular}

The level of enteric viruses throughout gastroenteritis can be as elevated as $10^{10}$ $10^{12}$ per gram of feces [1].

Pathogenic microorganisms commonly arise from an infected host (either human or either animal), or directly from nature. Numerous human pathogens could only be transmitted via direct or near contact with an infected person or animal. Examples comprise the herpes virus, Neisseria gonorrhoeae (gonorrhea), and Treponema pallidum (syphilis). This is due to the fact their survival period outside the host is quite short. Pathogens transmitted through nature can survive from hrs to years outside the host, depending on the organism and nature. Pathogens could exit a host in respiratory secretions from the nose and mouth, or be shed on dead skin or in feces, urine, saliva, or tears. Therefore, they may pollute the air, water, food, or inanimate objects (fomites) [1]. When polluted air is inhaled or food consumed, the organisms are efficiently transmitted to another host, where the infection phenomenon starts again. Airborne transmission could happen through liberation from the host in droplets (i.e., coughing) or via natural (surf at a beach) or human activities (cooling towers, showers) [1]. Several organisms could be carried important distances, hundreds of meters (like Legionnaires' disease and foot-and-mouth disease). Virus transmission via the airborne pathway can be both direct and indirect. Infection of a host may be by direct inhalation of infectious droplets or via contact with fomites on which the airborne droplets have settled. Hand or mouth contact with the organism on the surface of fomite leads to the transfer of the organism to the portal of entry, i.e., nose, mouth, or eye [1].

Microorganisms transmitted by the fecal-oral pathway are commonly mentioned as enteric pathogens since they spread the disease to the gastrointestinal 
tract. They are peculiarly stable in water and food, and, in the instance of enteric bacteria, are apt for development outside the host under the suitable ecological conditions [1].

Waterborne diseases (Table 3) are those transmitted via the ingestion of polluted water that works as the passive carrier of the infectious agent. The traditional waterborne diseases, cholera and typhoid fever, which have considerably damaged densely populated regions during human history, have been efficiently dominated via the protection of water sources and via the treatment of polluted water supplies. Indeed, dominating such traditional diseases lights the significance of water supply treatment which greatly contributed to the decrease of infectious illnesses. Additional illnesses provoked by bacteria, viruses, protozoa, and helminths may as well be transmitted via polluted potable water. Nevertheless, it is crucial to keep in mind that waterborne diseases are transmitted by the fecal-oral route, from human to human or animal to human, so that potable water is only one of numerous probable sources of infection [1].

Water-washed illnesses are intimately related to bad hygiene and wrong sanitation. In such a situation, the accessibility of enough amount of water is usually viewed as more significant than the standard of the water. The shortage of water for washing and bathing participates in illnesses that have an effect on the eye and skin, comprising infectious conjunctivitis and trachoma, as well as in diarrhea diseases, which are a prime source of infant mortality and morbidity in poor countries. Diarrheal illnesses could be immediately transmitted via person-to-person contact, or indirectly via contact with infected foods and utensils employed by persons whose hands are fecally polluted. When sufficient water is accessible for hand washing, the happening of diarrheal illnesses has been illustrated to lower considerably, as has the prevalence of enteric pathogens like Shigella [1].

Water-based illnesses are provoked by pathogens that either spend all (or crucial parts) of their lives in water or depend on aquatic organisms for the completion of their life cycles. Instances of these organisms are the parasitic helminth Schistosoma and the bacterium Legionella, which lead to schistosomiasis and Legionnaires' disease, respectively [1].

Table 3. Classification of water-related illnesses associated with microorganisms [1].

\begin{tabular}{|c|c|c|}
\hline Class & Cause & Example \\
\hline Waterborne & $\begin{array}{l}\text { Pathogens that originate in fecal material and are trans- } \\
\text { mitted by ingestion }\end{array}$ & Cholera, typhoid fever \\
\hline Water-washed & $\begin{array}{l}\text { Organisms that originate in feces are transmitted through } \\
\text { contact because of inadequate sanitation or hygiene }\end{array}$ & Trachoma \\
\hline Water-based & $\begin{array}{l}\text { Organisms that originate in the water or spend part of } \\
\text { their life cycle in aquatic animals and come in direct } \\
\text { contact with humans in water or by inhalation }\end{array}$ & $\begin{array}{l}\text { Schistosomiasis, } \\
\text { Legionellosis }\end{array}$ \\
\hline Water-related & $\begin{array}{l}\text { Microorganisms with life cycles associated with insects } \\
\text { that live or breed in water }\end{array}$ & Yellow fever \\
\hline
\end{tabular}


Water-related illnesses, like yellow fever, dengue, filariasis, malaria, onchocerciasis, and sleeping sickness, are transmitted via insects that multiply in water (like mosquitoes that transfer malaria) or live near water (e.g., the flies that transmit the filarial infection onchocerciasis). Such insects are known as vectors [1].

In spite of the considerable development registered in microbiology, humankind remains incapable to dominate scientifically and technologically the huge microbial world. This is well established and illustrated, unfortunately, in the present Coronavirus disease (COVID-19) pandemic. This work aims to contribute to highlight the world of pathogenic microorganisms. A special interest will be accorded to viruses. A general view on the fate and transport of enteric pathogens in nature will be presented. Since water treatment constitutes a secure barrier against drinking water infection, a brief presentation of the main stages in the conventional water treatment plant dealing with pathogens will be given. Finally, some research trends in the field of eliminating pathogens will be suggested.

\section{Viruses Background}

\subsection{Enteric Viruses}

Throughout the globe, viruses are a most important reason for gastroenteritis, especially in infants and young children, in which they are the main reason for mortality. Four main groups of human gastroenteritis viruses have been classified: rotavirus (Figure 1); enteric adenovirus (Figure 2); caliciviruses (norovirus and Sapporo virus); and astrovirus (Table 4). From these, norovirus is of concern since it has become the enteric virus most frequently related to water- and foodborne disease throughout the globe. Even if endemic viral gastroenteritis could be transmitted person to person by the oral-fecal pathway, eruptions of viral gastroenteritis can be initiated through infection of common water or food source [1].

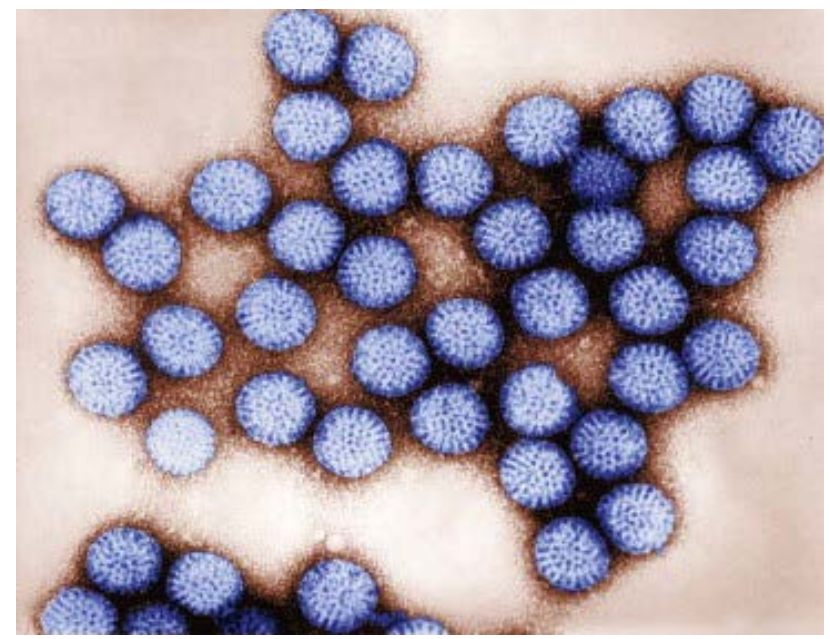

Figure 1. Electron micrograph of human rotavirus [1]. 


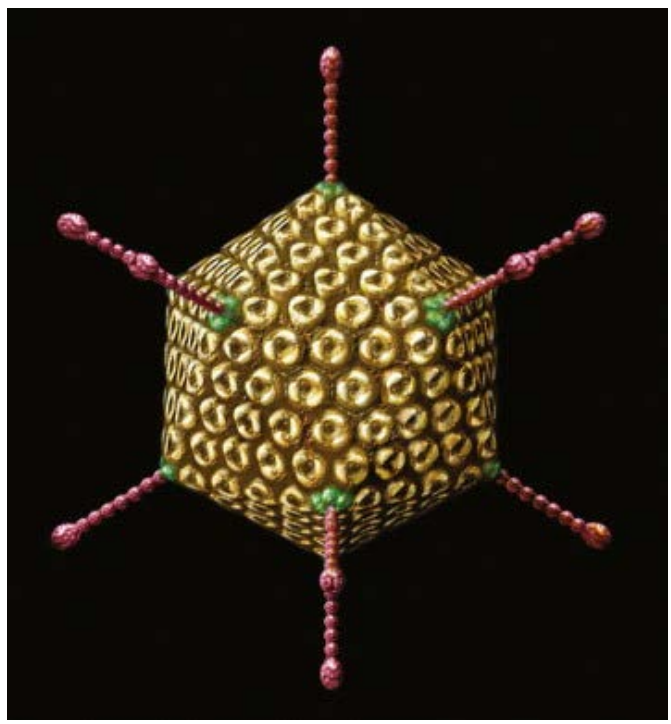

Figure 2. Adenovirus [1].

Table 4. Human enteric viruses [1].

Enterovirus
Hepatitis A virus
Reoviruses
Rotaviruses
Adenoviruses
Astroviruses
Torovirus
Human caliciviruses (norovirus, Sapporo virus)
Hepatitis E virus
Picobirnaviruses
Bocaviruses
Coronaviruses

Several human viruses could contaminate the gastrointestinal tract and be excreted in the feces into nature. A person with an enteric viral infection can excrete $10^{11}$ viral particles per gram of feces (Table 2). Once in nature, viruses could attain water supplies, recreational waters, crops, and shellfish, via contact with sewage, land runoff, solid waste landfills, and septic tanks [1].

Illnesses provoked via enteric viruses spread from slight to dangerous or even deadly. Waterborne eruptions formed by enteric viruses are complicated to report since numerous infections by such pathogens are subclinical. It means that the virus may replicate in a person, leading to virus shedding even if without symptoms of the apparent disease. On that account, a person with waterborne contamination but without apparent illness can contaminate others, who in turn can become ill, diffusing the infection throughout the society. Moreover, epide- 
miological techniques lack the responsiveness to discover low-level transmission of viruses via the water. Recreational activities in swimming pools have sometimes resulted in waterborne outbreaks caused by norovirus, hepatitis A virus, coxsackievirus (Figure 3), echovirus, and adenoviruses. Enteric viruses from contaminated persons could pollute recreational waters via direct contact or by fecal release [1].

\subsection{Respiratory Viruses}

Throughout the globe, respiratory diseases are the most frequent diseases in humans and most possess a viral etiology. Respiratory illness is related to a big number of viruses, comprising rhinoviruses (Figure 4); coronaviruses; parainfluenza viruses; respiratory syncytial virus; influenza virus; and adenovirus. Such

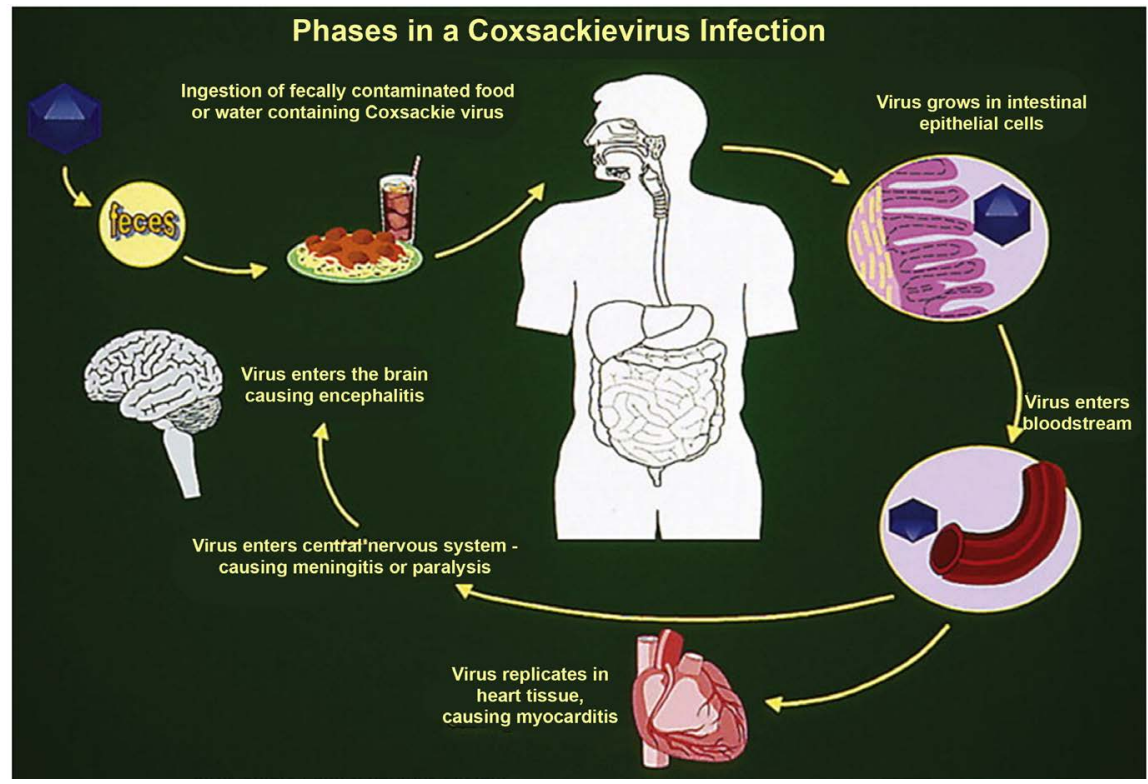

Figure 3. Infection by coxsackieviruses [1].

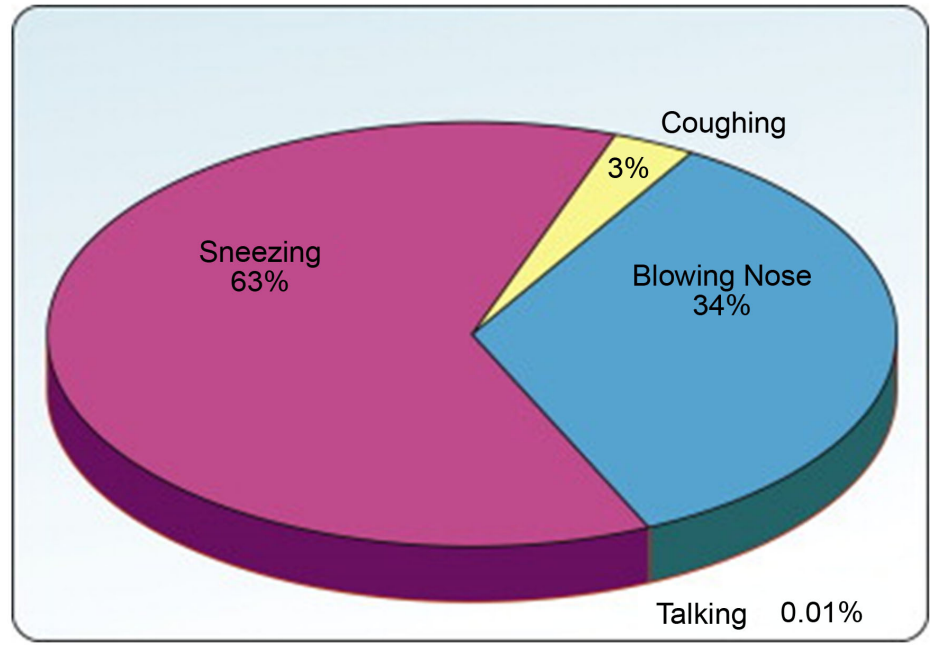

Figure 4. Source of rhinovirus dispersion [1]. 
viruses, when they contaminate the upper respiratory tract, could provoke acute viral rhinitis or pharyngitis (common cold); when the primary site of infection is the lower respiratory tract, they could lead to laryngotracheitis (croup), bronchitis or pneumonia [1].

Mortality linked to acute respiratory illness could be particularly considerable in children and in the elderly. In adults, temporary disability leads to huge economic loss. Respiratory infection frequently results from self-inoculation, when virus-contaminated hands or fingers rub the eyes or when viruses are introduced into the mouth or nose. Another significant pathway of transmission of respiratory viruses is the inhalation of contaminated aerosols [1].

\section{Fate and Transport of Enteric Pathogens in Nature}

There are numerous possible pathways for the transmission of excreted enteric pathogens. The possibility of an enteric pathogen to be transmitted by any of such pathways relies considerably on its resistance to ecological features, which dominate its survival and its capability to be transferred by water or air, as it moves through the environment. Numerous pathways could be categorized as "natural" pathways for the transmission of waterborne illness; however, others (like the usage of urban wastewater for groundwater recharge, large-scale aquaculture projects, or land disposal of disposable diapers) are in fact novel pathways generated by modern human activities [1].

Human and animal excreta are sources of pathogens. Persons become contaminated via pathogens during consumption of polluted foods, like shellfish from infected waters or crops irrigated with wastewater; from potable polluted water; and via vulnerability to polluted surface waters, as may happen throughout bathing or at recreational sites. Moreover, such humans contaminated by the above routes become sources of pollution via their excrement, thereby completing the cycle [1].

In the main, viral and protozoan pathogens survive longer in nature than enteric bacterial pathogens (Table 5). How long a pathogen survives in a specific medium is a function of many complicated characteristics (Table 6). Of all of the elements, the temperature remains likely the most significant. Temperature is a well-defined element with a systematically anticipated impact on enteric pathogen survival in nature. As a rule, the lower the temperature, the longer the survival time. Nevertheless, freezing temperatures usually conduct to the death of enteric bacteria and protozoan parasites. Even so, enteric viruses could stay infectious for months or years at freezing temperatures. Moisture-or lack thereof-could provoke reduced survival, and ultraviolet (UV) light from the sun is the main element in the demobilization of indicator bacteria in surface waters; therefore, die-off in marine waters could be anticipated by amount of exposure to daylight. Viruses stay much more resistant to demobilization by UV light [1] [21] [22].

Several laboratory investigations have established that the microflorae of natural waters and sewage are hostile to the survival of enteric pathogens [23] [24]. 
Table 5. Survival times of enteric pathogens in water, wastewater, and soil and on crops $[1]$.

\begin{tabular}{ccc}
\hline Enteric pathogen & Excreted load $^{\mathrm{a}}$ & Survival (months) $^{\mathrm{b}}$ \\
\hline Campylobacterspp. & $10^{7}$ & $1 / 3$ \\
Giardia lamblia & $10^{5}$ & $2 / 3$ \\
Shigella spp. & $10^{7}$ & 1 \\
Vibrio cholerae & $10^{7}$ & 1 \\
Salmonella spp. & $10^{8}$ & 3 \\
E. coli (pathogens) & $10^{8}$ & 3 \\
Enteroviruses & $10^{7}$ & 3 \\
Hepatitis A virus & $10^{6}$ & 3 \\
Ancylostoma duodenale & $10^{2}$ & 3 \\
Taenia saginata & $10^{4}$ & 9 \\
Ascaris lumbricoides & $10^{4}$ & 12 \\
\hline
\end{tabular}

${ }^{\mathrm{a} T y p i c a l ~ a v e r a g e ~ n u m b e r ~ o f ~ o r g a n i s m s / g ~ f e c e s . ~}{ }^{\mathrm{b}}$ Estimated average life of infective stage at $20^{\circ} \mathrm{C}-30^{\circ} \mathrm{C}$.

Table 6. Ecological elements influencing enteric pathogen survival in natural waters [1].

\begin{tabular}{cl}
\hline Element & \multicolumn{1}{c}{ Remarks } \\
\hline Temperature & $\begin{array}{l}\text { Probably the most important factor; longer survival at lower } \\
\text { temperatures; freezing kills bacteria and protozoan parasites, but } \\
\text { prolongs virus survival. }\end{array}$ \\
Moisture & Low moisture content in soil can reduce bacterial populations. \\
Light & UV in sunlight is harmful. \\
pH & $\begin{array}{l}\text { Most are stable at pH values of natural waters. Enteric bacteria are } \\
\text { less stable at pH }>9 \text { and pH }<6 .\end{array}$ \\
Salts & $\begin{array}{l}\text { Some viruses are protected against heat inactivation by the } \\
\text { presence of certain cations. }\end{array}$ \\
Organic matter & The presence of sewage usually results in longer survival. \\
Biological factors & $\begin{array}{l}\text { Association with solids prolongs survival of enteric bacteria and } \\
\text { virus. }\end{array}$ \\
\hline
\end{tabular}

As an illustration, enteric pathogens survive longer in sterile water than in water from lakes, rivers and oceans. Bacteria in natural waters can feed upon indicator bacteria [25]. Suspended matter (clays, organic debris, and the like) and fresh or marine sediments have been shown to prolong their survival time (Figure 5) [1] [26].

\section{Conventional Potable Water Treatment}

Rivers, streams, lakes, and underground aquifers remain latent sources of drinking water [2]. All water acquired from surface sources has to be filtered and disinfected to keep safe from the danger of microbial pollutants [27] [28] [29]. This 


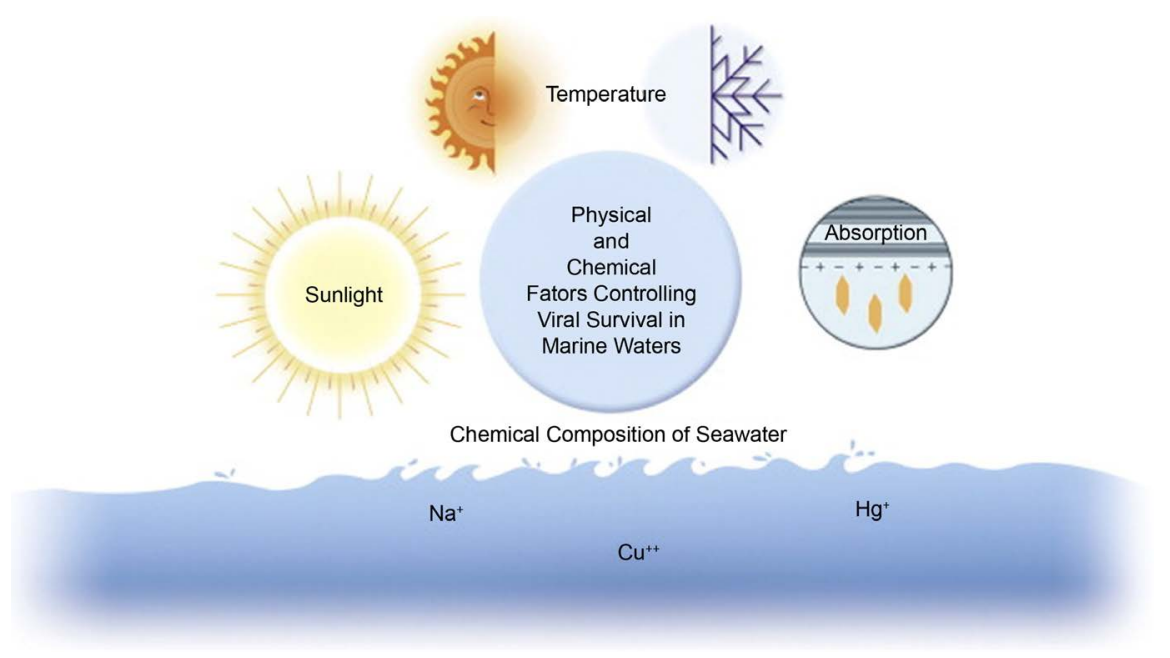

Figure 5. Elements influencing the survival of enteric bacteria, and viral pathogens in seawater [1].

treatment of surface waters also enhances esthetic features like the taste, color, and odor [30] [31] [32]. Further, groundwater, as it is below the direct impact of surface waters like nearby rivers, has to be treated as if it was a surface supply [33] [34] [35]. In several situations, nevertheless, groundwater requires either no treatment or only disinfection before human consumption. This is thanks to the soil itself has worked as a filter to retain pathogens, averting the hazards of pollution of drinking water supplies.

Before anything else, slow sand filtration was the single method used for purifying public water supplies [1] [2] [36]. After that, things started to alter. In 1881, Koch proved in the laboratory that chlorine can neutralize microbe [37] [38] [39]. Following an eruption of typhoid fever in London, continuous chlorination of public water supply was utilized for the first time in 1905 [40] [41]. The methodical usage of disinfection in the United States started in Chicago in 1908. Implementing present-day water treatment technologies had a main effect on water-transmitted illnesses like typhoid in the United States (Figure 6) [2].

Recent water treatment engineering furnishes barriers against waterborne illnesses [42] [43] [44]. Such barriers, if applied as a sequence of treatment techniques, are famous as a treatment process train (Figure 7) [2] [45] [46]. The easiest treatment process train, familiar as chlorination, is composed of only one treatment method, disinfection via chlorination (Figure 7(A)) [47] [48] [49]. The treatment technique train, renowned as filtration, involves chlorination pursued via filtration across sand or coal that retains particulate matter from the water and decreases turbidity (Figure 7(B)) [50] [51] [52]. At the following stage of treatment, in-line filtration, a coagulant is introduced before filtration (Figure 7(C)) [53] [54] [55]. Coagulation modifies the physicochemical state of both dissolved and suspended solids and accelerates their elimination through filtration [56] [57] [58]. More traditional water treatment plants combine a flocculation (slow mixing) stage ahead filtration, which ameliorates the aggregation of 


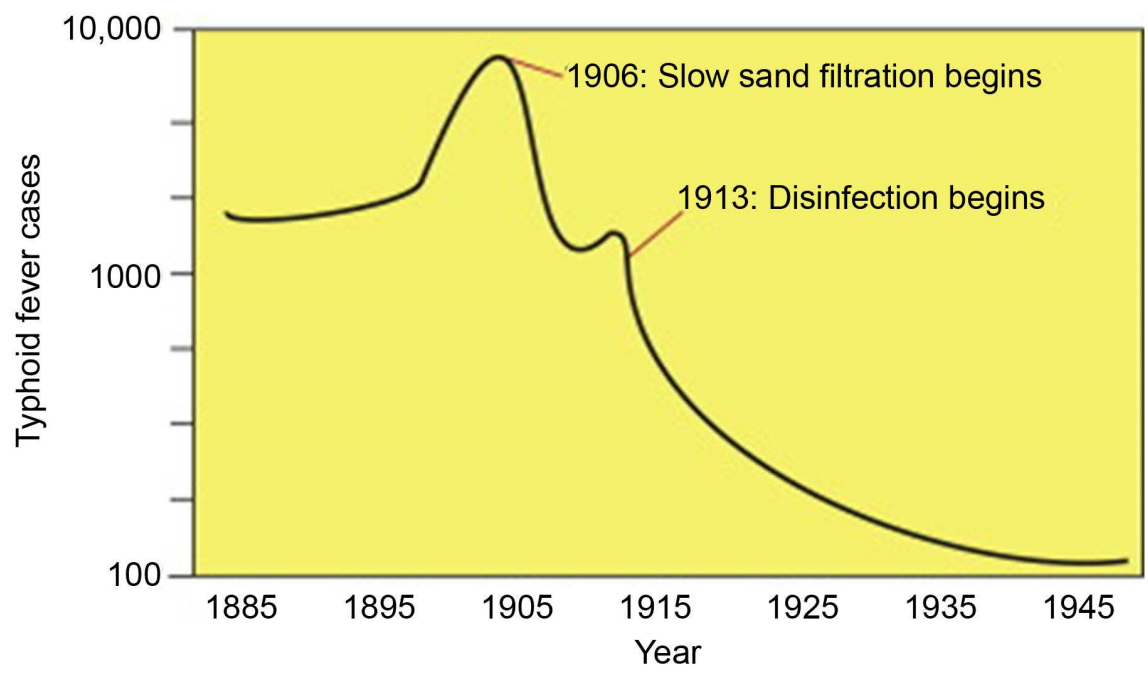

Figure 6. Influence of water filtration and chlorination on typhoid fever death rate in Albany, New York [2].

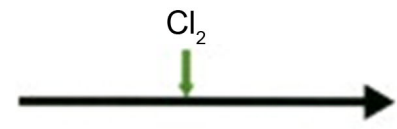

\section{Chlorination}

(A)

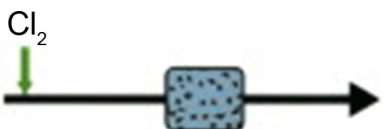

Filtration

(B)

Filtration

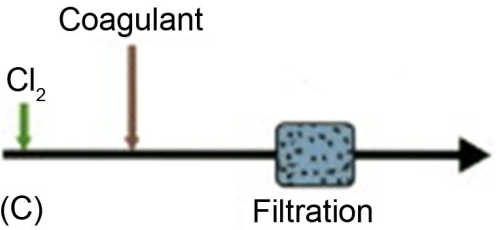

In-Line

(C)

Filtration

Filtration

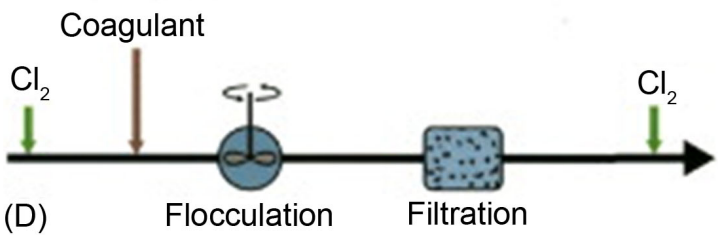

Direct

(D)

Flocculation

Filtration

Filtration

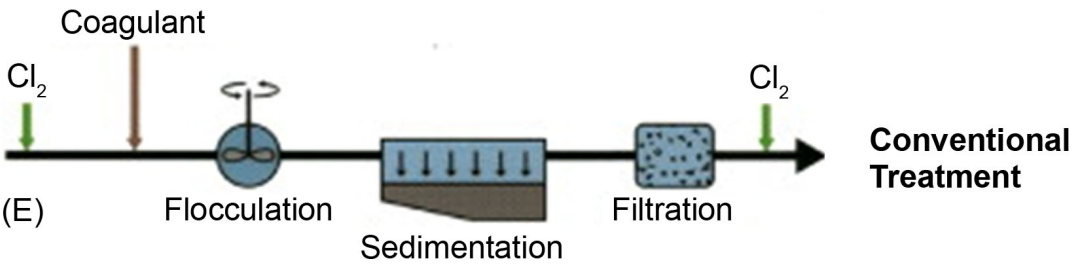

Figure 7. Usual water treatment process trains [2].

flocs, and then enhances the elimination performance in a treatment technique train named direct filtration (Figure 7(D)) [59] [60] [61]. In direct filtration, 
disinfection is ameliorated through injecting chlorine (or substitutional disinfectant, like chlorine dioxide or ozone) at both the commencement and termination of the process train [62] [63] [64]. The most frequent treatment process train for surface water supplies, famous as traditional treatment, is composed of disinfection, coagulation, flocculation, sedimentation, filtration, and disinfection (Figure 7(E)) [2] [65] [66].

Coagulation implicates the introduction of chemicals to accelerate the elimination of dissolved and suspended matters through sedimentation and filtration [67] [68] [69]. The most frequent coagulants are hydrolyzing iron salts [70] [71], ferric sulfate $\left(\mathrm{Fe}_{2}\left(\mathrm{SO}_{4}\right)_{3}\right)$ and ferric chloride $\left(\mathrm{FeCl}_{3}\right)$ [72] [73] [74]. Coagulation could as well reduce dissolved organic and inorganic compounds [75] [76] [77]. Iron hydrolyzing metal salts injected to the water can react with the organic matter to form a precipitate, or they may form ferric hydroxide floc particles to which the organic molecules adsorb [78] [79] [80]. The organic matter is then retained through sedimentation and filtration, or filtration alone if direct filtration or in-line filtration is used [2] [32] [81].

Flocculation is a simple physical process in which the treated water is softly stirred to augment interparticle collisions, so encouraging the generation of big flocs [82] [83] [84]. Following convenient flocculation, most of the flocs settle out throughout the step of sedimentation $(1-2 \mathrm{~h})$ [85] [86] [87]. Microorganisms are entrapped or adsorbed to the suspended particles and retained through sedimentation [2] [88] [89].

Sedimentation is one more entirely physical method, implying the gravitational settling of suspended solids that are denser than water [22] [90] [91]. The resulting effluent is then subjected to rapid filtration to retain solids that are still suspended in the water [92] [93] [94]. Rapid filters are commonly composed of $50-75 \mathrm{~cm}$ of sand and/or anthracite, having a diameter between 0.5 and $1.0 \mathrm{~mm}$ [95]. Details that affect pathogen elimination via filtration are temperature, sand grain size, filter depth, flow rate, and well-developed biofilm layer [2] [96] [97].

Considered jointly, coagulation, flocculation, sedimentation, and filtration efficiently eliminate several pollutants (Table 7) [98] [99] [100]. To the same level crucial, they remove turbidity, rendering water of fine limpidity and so improved disinfection efficacy [101] [102] [103]. If not retained by these techniques, particles

Table 7. Coagulation, sedimentation, filtration: Usual removal efficiencies and effluent quality [2].

\begin{tabular}{cccc}
\hline Organisms & $\begin{array}{c}\text { Coagulation and } \\
\text { sedimentation (\% removal) }\end{array}$ & $\begin{array}{c}\text { Rapid filtration } \\
\text { (\% removal) }\end{array}$ & $\begin{array}{c}\text { Slow sand filtration } \\
\text { (\% removal) }\end{array}$ \\
\hline Total coliforms & $74-97$ & $50-98$ & $>99.999$ \\
Fecal coliforms & $76-83$ & $50-98$ & $>99.999$ \\
Enteric viruses & $88-95$ & $10-99$ & $>99.999$ \\
Giardia & $58-99$ & $97-99.9$ & $>99$ \\
Cryptosporidium & 90 & $99-99.9$ & 99 \\
\hline
\end{tabular}


can hide pathogens and bring about ultimate disinfection more complicated [104] [105] [106]. Filtration is a particularly essential barrier in eliminating protozoan parasites Giardia lamblia and Cryptosporidium [107]. Indeed, the cysts and oocysts of such microorganisms are extremely resistant to demobilization via disinfectants [2]. Therefore, disinfection by oneself cannot be relied on to avoid waterborne diseases [1] [108] [109]. Nevertheless, due to their smaller size, viruses and bacteria could travel across the filtration technique. Eliminating viruses via coagulation and filtration relies on their fixing on solids (adsorption), which is a function of the surface charge of the virus. This is linked to the isoelectric point (the $\mathrm{pH}$ at which the virus has no charge) and is both strain and type-dependent (Table 8) [3]. The changes in surface characteristics have been employed to interpret why diverse kinds of viruses are retained with changing performances via coagulation and filtration [2]. Consequently, disinfection stays the final barrier to such pathogens [110] [111] [112].

As a rule, disinfection is realized during the introduction of an oxidant. Chlorine stays out and away the most frequent disinfectant utilized to treat potable water; however, different oxidants, like chloramines, chlorine dioxide, and ozone are as well employed [2].

\section{Eliminating Pathogens from Drinking Water: Research Trends}

As shown in Table 6, there are several environmental parameters affecting enteric

Table 8. Influence of main natural elements on microbial diversity [3].

\begin{tabular}{|c|c|}
\hline Element & Effect on microbial diversity \\
\hline $\mathrm{pH}$ & $\begin{array}{l}\text { Maximum diversity at neutral } \mathrm{pH}(6-8) \text {. Extreme } \mathrm{pHs} \text { lead to decreased } \\
\text { diversity. }\end{array}$ \\
\hline Vegetation & $\begin{array}{l}\text { Different plants may stimulate and/or inhibit different microbial } \\
\text { populations. }\end{array}$ \\
\hline Water content & $\begin{array}{l}\text { Greater diversity with moderate water content. Water-saturated } \\
\text { conditions decrease diversity due to less spatial isolation of organisms } \\
\text { and also the generation of anaerobic conditions. }\end{array}$ \\
\hline Oxygen concentration & Greater diversity under aerobic conditions. \\
\hline Temperature & Extremely high or low temperatures reduce diversity. \\
\hline Organic matter content & Higher organic matter content results in higher diversity. \\
\hline Soil depth & Decreasing diversity with increasing depth from surface. \\
\hline $\begin{array}{l}\text { Addition of organic } \\
\text { substrates }\end{array}$ & $\begin{array}{l}\text { Addition of a single, organic substrate often results in a reduction in } \\
\text { diversity due to the stimulation of a subset of the microbial community. }\end{array}$ \\
\hline Soil tillage & $\begin{array}{l}\text { Decreased diversity due to soil homogenization and reduction in } \\
\text { microsite variation. }\end{array}$ \\
\hline $\begin{array}{l}\text { Addition of organic } \\
\text { pollutants }\end{array}$ & $\begin{array}{l}\text { Similar to organic substrates in general, often a reduction in diversity due } \\
\text { to stimulation of specific populations but also potentially toxicity of the } \\
\text { xenobiotic to other populations. }\end{array}$ \\
\hline $\begin{array}{l}\text { Addition of metal } \\
\text { pollutants }\end{array}$ & Reduction in diversity due to toxicity to some populations. \\
\hline
\end{tabular}


pathogen survival in natural waters [1]. Increasing temperature and UV irradiation (sunlight) are most unfavorable for pathogens survival in water. This means that those elements are favorable for removing microorganisms from water.

A few years ago, the concept of the best available technology of water/wastewater treatment and seawater desalination which is, in fact, a simulation of the seawater distillation at the open sky: coagulation in salty water aerated basin/coagulation using seawater as coagulant solution with distillation using stored solar energy followed by a waterfall on a natural mountain was suggested [26]. Such a natural, green, and technico-economical technology is composed of three steps: the first one is coagulation which may be achieved: 1) in salty water aerated basin (air stripping, AS; dissolved air flotation, DAF) where the raw water is "diluted" in seawater; or 2) in "conventional" coagulation using seawater as coagulant solution instead of alum/ferric salts. The first option seems to be more natural as it simulates river water dilution in seawater and the second one is more practical for "rapid" water consummation. For colloids and microorganisms' removal, double-layer compression and charge neutralization, as main coagulation and disinfection mechanisms, would be involved in the first and second options, respectively. Aerated basin (AS/DAF) reproduces the natural aeration to simulate a healthy natural water basin. Using stored solar energy, distillation as the best liquid-solid/liquid-liquid separation process provides the removal of dissolved pollutants. For well-balanced calco-carbonic equilibrium, the last step of this green treatment is the waterfall on a natural mountain providing useful gases, dissolved oxygen and carbon dioxide, and mineral salts to the water [26] [27].

It is well established that the drinking water treatment has several disadvantages such as it may rupture the algae, thereby releasing the taste- and odor-producing oils before the whole algae are removed from the treatment system. The concept of algae recovery instead of its removal in drinking water treatment plant was suggested [43]. In fact, algae recovery instead of its removal in water treatment plant is a promising perspective and a suitable issue when the surface water comes from dams where algae blooms occur frequently. Micro-algae are a sustainable energy resource with great potential for $\mathrm{CO}_{2}$ fixation. The micro-algae could be grown in photo-bioreactors or in open ponds. A new interesting field of research would be fast and simultaneous algal biodiesel production with drinking water treatment in the biodiesel production/water treatment plant without chemicals [43]. Such green technology will remove simultaneously pathogens.

\section{Conclusion}

In spite of the considerable development registered in microbiology, humans stay incapable to dominate scientifically and technologically the huge microbial world. This is well established and illustrated, unfortunately, in the present Coronavirus disease (COVID-19) pandemic. This work focuses on the world of pathogenic microorganisms, especially viruses, and their removal from potable water. Identical to the manner by which chemical contaminants are handled in the environment, the particular properties that control transport and demobili- 
zation of enveloped viruses in solutions, on surfaces, and in the air must be understood. Besides, the fashion by which ecological parameters form likely virus transmission and mutation mechanisms should be comprehended. Since water treatment constitutes a secure barrier against drinking water infection, the main stages in the conventional water treatment plant dealing with pathogens have to be enhanced with more efficient techniques such as advanced oxidations processes. In the field of eliminating pathogens, some promising techniques are suggested especially those founded on thermal destruction and solar irradiation due to their high performance and low costs.

\section{Acknowledgements}

This research has been funded by the Research Deanship of University of Ha'il, Saudi Arabia, through the Project RG-191190.

\section{Conflicts of Interest}

The author declares no conflicts of interest regarding the publication of this paper.

\section{References}

[1] Gerba, C.P. (2015) Environmentally Transmitted Pathogens, Ch. 22. In: Pepper, I.L., Gerba, C.P. and Gentry, T.J., Eds., Environmental Microbiology, 3rd Edition, Elsevier Inc., Houston, 509-550. https://doi.org/10.1016/B978-0-12-394626-3.00022-3

[2] Gerba, C.P. and Pepper, I.L. (2015) Drinking Water Treatment and Distribution, Ch. 28. In: Pepper, I.L., Gerba, C.P. and Gentry, T.J., Eds., Environmental Microbiology, 3rd Edition, Elsevier Inc., Houston, 633-643.

https://doi.org/10.1016/B978-0-12-394626-3.00028-4

[3] Gentry, T.J., Pepper, I.L. and Pierson III, L.S. (2015) Microbial Diversity and Interactions in Natural Ecosystems, Ch. 19. In: Pepper, I.L., Gerba, C.P. and Gentry, T.J., Eds., Environmental Microbiology, 3rd Edition, Elsevier Inc., Houston, 441-460. https://doi.org/10.1016/B978-0-12-394626-3.00019-3

[4] Ghernaout, D. and Elboughdiri, N. (2020) Environmental Engineering for Stopping Viruses Pandemics. Open Access Library Journal, 7, e6299.

[5] Ghernaout, D. and Elboughdiri, N. (2020) Disinfecting Water: Plasma Discharge for Removing Coronaviruses. Open Access Library Journal, 7, e6314. https://doi.org/10.4236/oalib.1106314

[6] Ghernaout, D. (2019) Virus Removal by Electrocoagulation and Electrooxidation: New Findings and Future Trends. Journal of Environmental Science and Allied Research, 2019, 85-90.

[7] Ghernaout, D. and Elboughdiri, N. (2020) Electrocoagulation Process in the Context of Disinfection Mechanism. Open Access Library Journal, 7, e6083.

[8] Ghernaout, D. and Elboughdiri, N. (2019) Water Disinfection: Ferrate(VI) as the Greenest Chemical-A Review. Applied Engineering, 3, 171-180.

[9] Ghernaout, D. and Elboughdiri, N. (2020) Strategies for Reducing Disinfection By-Products Formation during Electrocoagulation. Open Access Library Journal, 7, e6076. https://doi.org/10.4236/oalib.1106076 
[10] Ghernaout, D. and Elboughdiri, N. (2020) Disinfection By-Products: Presence and Elimination in Drinking Water. Open Access Library Journal, 7, e6140.

[11] Ghernaout, D. and Elboughdiri, N. (2020) Controlling Disinfection By-Products Formation in Rainwater: Technologies and Trends. Open Access Library Journal, 7, e6162. https://doi.org/10.4236/oalib.1106162

[12] Ghernaout, D. and Elboughdiri, N. (2020) Towards Enhancing Ozone Diffusion for Water Disinfection-Short Notes. Open Access Library Journal, 7, e6253. https://doi.org/10.4236/oalib.1106253

[13] Ghernaout, D., Elboughdiri, N., Alghamdi, A. and Ghernaout, B. (2020) Trends in Decreasing Disinfection By-Products Formation during Electrochemical Technologies. Open Access Library Journal, 7, e6337. https://doi.org/10.4236/oalib.1106337

[14] Ghernaout, D. and Elboughdiri, N. (2020) Foresight Look on the Disinfection By-Products Formation. Open Access Library Journal, 7, e6349.

[15] Ghernaout, D. (2017) Environmental Principles in the Holy Koran and the Sayings of the Prophet Muhammad. American Journal of Environmental Protection, 6, 75-79. https://doi.org/10.11648/j.ajep.20170603.13

[16] Ghernaout, D., Ghernaout, B. and Naceur, M.W. (2011) Embodying the Chemical Water Treatment in the Green Chemistry-A Review. Desalination, 271, 1-10. https://doi.org/10.1016/j.desal.2011.01.032

[17] Ghernaout, D., Badis, A., Ghernaout, B. and Kellil, A. (2008) Application of Electrocoagulation in Escherichia coli Culture and Two Surface Waters. Desalination, 219, 118-125. https://doi.org/10.1016/j.desal.2007.05.010

[18] Ghernaout, D. and Elboughdiri, N. (2020) Antibiotics Resistance in Water Mediums: Background, Facts, and Trends. Applied Engineering, 4, 1-6. https://doi.org/10.4236/oalib.1106003

[19] Ghernaout, D. and Elboughdiri, N. (2020) Removing Antibiotic-Resistant Bacteria (ARB) Carrying Genes (ARGs): Challenges and Future Trends. Open Access Library Journal, 7, e6003. https://doi.org/10.4236/oalib.1106003

[20] Ghernaout, D. and Elboughdiri, N. (2020) Should We Forbid the Consumption of Antibiotics to Stop the Spread of Resistances in Nature? Open Access Library Journal, 7, e6138.

[21] Ghernaout, D. and Elboughdiri, N. (2020) Vacuum-UV Radiation at $185 \mathrm{~nm}$ for Disinfecting Water. Chemical Science \& Engineering Research, 2, 12-17.

[22] Ghernaout, D. and Elboughdiri, N. (2020) UV-C/ $\mathrm{H}_{2} \mathrm{O}_{2}$ and Sunlight $/ \mathrm{H}_{2} \mathrm{O}_{2}$ in the Core of the Best Available Technologies for Dealing with Present Dares in Domestic Wastewater Reuse. Open Access Library Journal, 7, e6161. https://doi.org/10.4236/oalib.1106161

[23] Ghernaout, D. (2018) Increasing Trends towards Drinking Water Reclamation from Treated Wastewater. World Journal of Applied Chemistry, 3, 1-9. https://doi.org/10.11648/j.wjac.20180301.11

[24] Ghernaout, D. (2017) Water Reuse (WR): The Ultimate and Vital Solution for Water Supply Issues. International Journal of Sustainable Development Research, 3, 36-46. https://doi.org/10.11648/j.ijsdr.20170304.12

[25] Ghernaout, D., Benblidia, C. and Khemici, F. (2015) Microalgae Removal from Ghrib Dam (Ain Defla, Algeria) Water by Electroflotation Using Stainless Steel Electrodes. Desalination and Water Treatment, 54, 3328-3337. https://doi.org/10.1080/19443994.2014.907749

[26] Ghernaout, D. (2013) The Best Available Technology of Water/Wastewater Treat- 
ment and Seawater Desalination: Simulation of the Open Sky Seawater Distillation. Green \& Sustainable Chemistry, 3, 68-88. https://doi.org/10.4236/gsc.2013.32012

[27] Ghernaout, D. and Elboughdiri, N. (2020) Solar Treatment in the Core of the New Disinfection Technologies. Chemical Science \& Engineering Research, 2, 6-11.

[28] Ghernaout, D. and Ghernaout, B. (2010) From Chemical Disinfection to Electrodisinfection: The Obligatory Itinerary? Desalination and Water Treatment, 16, 156-175. https://doi.org/10.5004/dwt.2010.1085

[29] Boucherit, A., Moulay, S., Ghernaout, D., Al-Ghonamy, A.I., Ghernaout, B., Naceur, M.W., Ait Messaoudene, N., Aichouni, M., Mahjoubi, A.A. and Elboughdiri, N.A. (2015) New Trends in Disinfection By-Products Formation upon Water Treatment. Journal of Research \& Developments in Chemistry, 2015, Article ID: 628833.

[30] Ghernaout, D. (2017) Microorganisms' Electrochemical Disinfection Phenomena. EC Microbiology, 9, 160-169.

[31] Ghernaout, D. (2018) Disinfection and DBPs Removal in Drinking Water Treatment: A Perspective for a Green Technology. International Journal of Advances in Applied Sciences, 5, 108-117. https://doi.org/10.21833/ijaas.2018.02.018

[32] Ghernaout, D. (2019) Greening Electrocoagulation Process for Disinfecting Water. Applied Engineering, 3, 27-31.

[33] Ghernaout, D., Alghamdi, A. and Ghernaout, B. (2019) Microorganisms' Killing: Chemical Disinfection vs. Electrodisinfection. Applied Engineering, 3, 13-19.

[34] Ghernaout, D. (2019) Disinfection via Electrocoagulation Process: Implied Mechanisms and Future Tendencies. EC Microbiology, 15, 79-90.

[35] Ghernaout, D. and Elboughdiri, N. (2019) Mechanistic Insight into Disinfection Using Ferrate(VI). Open Access Library Journal, 6, e5946.

[36] Ait Messaoudene, N., Naceur, M.W., Ghernaout, D., Alghamdi, A. and Aichouni, M. (2018) On the Validation Perspectives of the Proposed Novel Dimensionless Fouling Index. International Journal of Advances in Applied Sciences, 5, 116-122. https://doi.org/10.21833/ijaas.2018.07.014

[37] Ghernaout, D., Naceur, M.W. and Aouabed, A. (2011) On the Dependence of Chlorine By-Products Generated Species Formation of the Electrode Material and Applied Charge during Electrochemical Water Treatment. Desalination, 270, 9-22. https://doi.org/10.1016/j.desal.2011.01.010

[38] Ghernaout, D., Moulay, S., Ait Messaoudene, N., Aichouni, M., Naceur, M.W. and Boucherit, A. (2014) Coagulation and Chlorination of NOM and Algae in Water Treatment: A Review. International Journal of Environmental Monitoring and Analysis, 2, 23-34. https://doi.org/10.11648/j.ijema.s.2014020601.14

[39] Ghernaout, D. (2017) Water Treatment Chlorination: An Updated Mechanistic Insight Review. Chemistry Research Journal, 2, 125-138.

[40] Ghernaout, D., Alghamdi, A., Aichouni, M. and Touahmia, M. (2018) The Lethal Water Tri-Therapy: Chlorine, Alum, and Polyelectrolyte. World Journal of Applied Chemistry, 3, 65-71. https://doi.org/10.11648/j.wjac.20180302.14

[41] Ghernaout, D. and Elboughdiri, N. (2020) Is Not It Time to Stop Using Chlorine for Treating Water? Open Access Library Journal, 7, e6007.

[42] Ghernaout, D. and Naceur, M.W. (2011) Ferrate(VI): In Situ Generation and Water Treatment-A Review. Desalination and Water Treatment, 30, 319-332. https://doi.org/10.5004/dwt.2011.2217

[43] Ghernaout, D. and Ghernaout, B. (2012) On the Concept of the Future Drinking Water Treatment Plant: Algae Harvesting from the Algal Biomass for Biodiesel 
Production-A Review. Desalination and Water Treatment, 49, 1-18. https://doi.org/10.1080/19443994.2012.708191

[44] Ghernaout, D., Badis, A., Braikia, G., Matâam, N., Fekhar, M., Ghernaout, B. and Boucherit, A. (2017) Enhanced Coagulation for Algae Removal in a Typical Algeria Water Treatment Plant. Environmental Engineering and Management Journal, 16, 2303-2315. https://doi.org/10.30638/eemj.2017.238

[45] Ghernaout, D. (2018) Magnetic Field Generation in the Water Treatment Perspectives: An Overview. International Journal of Advances in Applied Sciences, 5, 193-203. https://doi.org/10.21833/ijaas.2018.01.025

[46] Ghernaout, D., Aichouni, M. and Alghamdi, A. (2018) Applying Big Data (BD) in Water Treatment Industry: A New Era of Advance. International Journal of Advances in Applied Sciences, 5, 89-97. https://doi.org/10.21833/ijaas.2018.03.013

[47] Alshammari, Y., Ghernaout, D., Aichouni, M. and Touahmia, M. (2018) Improving Operational Procedures in Riyadh's (Saudi Arabia) Water Treatment Plants Using Quality Tools. Applied Engineering, 2, 60-71.

[48] Ghernaout, D. (2019) Greening Cold Fusion as an Energy Source for Water Treatment Distillation-A Perspective. American Journal of Quantum Chemistry and Molecular Spectroscopy, 3, 1-5.

[49] Ghernaout, D. (2019) Electrocoagulation Process for Microalgal Biotechnology-A Review. Applied Engineering, 3, 85-94.

[50] Ghernaout, D. and Elboughdiri, N. (2020) On the Treatment Trains for Municipal Wastewater Reuse for Irrigation. Open Access Library Journal, 7, e6088.

[51] Ghernaout, D. and Elboughdiri, N. (2020) Advanced Oxidation Processes for Wastewater Treatment: Facts and Future Trends. Open Access Library Journal, 7, e6139.

[52] Ghernaout, D., Ghernaout, B. and Kellil, A. (2009) Natural Organic Matter Removal and Enhanced Coagulation as a Link between Coagulation and Electrocoagulation. Desalination and Water Treatment, 2, 203-222. https://doi.org/10.5004/dwt.2009.116

[53] Ghernaout, D., Ghernaout, B., Saiba, A., Boucherit, A. and Kellil, A. (2009) Removal of Humic Acids by Continuous Electromagnetic Treatment Followed by Electrocoagulation in Batch Using Aluminium Electrodes. Desalination, 239, 295-308. https://doi.org/10.1016/j.desal.2008.04.001

[54] Ghernaout, D., Ghernaout, B. and Boucherit, A. (2008) Effect of pH on Electrocoagulation of Bentonite Suspensions in Batch Using Iron Electrodes. Journal of Dispersion Science and Technology, 29, 1272-1275.

https://doi.org/10.1080/01932690701857483

[55] Ghernaout, D., Ghernaout, B., Boucherit, A., Naceur, M.W., Khelifa, A. and Kellil, A. (2009) Study on Mechanism of Electrocoagulation with Iron Electrodes in Idealised Conditions and Electrocoagulation of Humic Acids Solution in Batch Using Aluminium Electrodes. Desalination and Water Treatment, 8, 91-99. https://doi.org/10.5004/dwt.2009.668

[56] Saiba, A., Kourdali, S., Ghernaout, B. and Ghernaout, D. (2010) In Desalination, from 1987 to 2009, the Birth of a New Seawater Pretreatment Process: Electrocoagulation-An Overview. Desalination and Water Treatment, 16, 201-217. https://doi.org/10.5004/dwt.2010.1094

[57] Belhout, D., Ghernaout, D., Djezzar-Douakh, S. and Kellil, A. (2010) Electrocoagulation of a Raw Water of Ghrib Dam (Algeria) in Batch Using Iron Electrodes. Desalination and Water Treatment, 16, 1-9. https://doi.org/10.5004/dwt.2010.1081 
[58] Ghernaout, B., Ghernaout, D. and Saiba, A. (2010) Algae and Cyanotoxins Removal by Coagulation/Flocculation: A Review. Desalination and Water Treatment, 20, 133-143. https://doi.org/10.5004/dwt.2010.1202

[59] Ghernaout, D., Mariche, A., Ghernaout, B. and Kellil, A. (2010)Electromagnetic Treatment-Bi-Electrocoagulation of Humic Acid in Continuous Mode Using Response Surface Method for Its Optimization and Application on Two Surface Waters. Desalination and Water Treatment, 22, 311-329. https://doi.org/10.5004/dwt.2010.1120

[60] Ghernaout, D. and Ghernaout, B. (2011) On the Controversial Effect of Sodium Sulphate as Supporting Electrolyte on Electrocoagulation Process: A Review. Desalination and Water Treatment, 27, 243-254. https://doi.org/10.5004/dwt.2011.1983

[61] Ghernaout, D., Naceur, M.W. and Ghernaout, B. (2011) A Review of Electrocoagulation as a Promising Coagulation Process for Improved Organic and Inorganic Matters Removal by Electrophoresis and Electroflotation. Desalination and Water Treatment, 28, 287-320. https://doi.org/10.5004/dwt.2011.1493

[62] Ghernaout, D. (2013) Advanced Oxidation Phenomena in Electrocoagulation Process: A Myth or a Reality? Desalination and Water Treatment, 51, 7536-7554. https://doi.org/10.1080/19443994.2013.792520

[63] Ghernaout, D., Irki, S. and Boucherit, A. (2014) Removal of $\mathrm{Cu}^{2+}$ and $\mathrm{Cd}^{2+}$, and Humic Acid and Phenol by Electrocoagulation Using Iron Electrodes. Desalination and Water Treatment, 52, 3256-3270. https://doi.org/10.1080/19443994.2013.852484

[64] Ghernaout, D. (2014) The Hydrophilic/Hydrophobic Ratio vs. Dissolved Organics Removal by Coagulation-A Review. Journal of King Saud University-Science, 26, 169-180. https://doi.org/10.1016/j.jksus.2013.09.005

[65] Ghernaout, D., Al-Ghonamy, A.I., Naceur, M.W., Ait Messaoudene, N. and Aichouni, M. (2014) Influence of Operating Parameters on Electrocoagulation of C.I. Disperse Yellow 3. Journal of Electrochemical Science and Engineering, 4, 271-283. https://doi.org/10.5599/jese.2014.0065

[66] Ghernaout, D., Al-Ghonamy, A.I., Irki, S., Grini, A., Naceur, M.W., Ait Messaoudene, N. and Aichouni, M. (2014) Decolourization of Bromophenol Blue by Electrocoagulation Process. Trends in Chemical Engineering, 15, 29-39.

[67] Ghernaout, D., Al-Ghonamy, A.I., Boucherit, A., Ghernaout, B., Naceur, M.W., Ait Messaoudene, N., Aichouni, M., Mahjoubi, A.A. and Elboughdiri, N.A. (2015) Brownian Motion and Coagulation Process. American Journal of Environmental Protection, 4, 1-15. https://doi.org/10.11648/j.ajeps.s.2015040501.11

[68] Ghernaout, D., Al-Ghonamy, A.I., Naceur, M.W., Boucherit, A., Messaoudene, N.A., Aichouni, M., Mahjoubi, A.A. and Elboughdiri, N.A. (2015) Controlling Coagulation Process: From Zeta Potential to Streaming Potential. American Journal of Environmental Protection, 4, 16-27. https://doi.org/10.11648/j.ajeps.s.2015040501.12

[69] Ghernaout, D., Al-Ghonamy, A.I., Ait Messaoudene, N., Aichouni, M., Naceur, M.W., Benchelighem, F.Z. and Boucherit, A. (2015) Electrocoagulation of Direct Brown 2 (DB) and BF Cibacete Blue (CB) Using Aluminum Electrodes. Separation Science and Technology, 50, 1413-1420. https://doi.org/10.1080/01496395.2014.982763

[70] Ghernaout, D. (2017) The Holy Koran Revelation: Iron Is a "Sent Down" Metal. American Journal of Environmental Protection, 6, 101-104.

https://doi.org/10.11648/j.ajep.20170604.14 
[71] Ghernaout, D., Laribi, C., Alghamdi, A., Ghernaout, B., Ait Messaoudene, N. and Aichouni, M. (2018) Decolorization of BF Cibacete Blue (CB) and Red Solophenyle 3BL (RS) Using Aluminum Sulfate and Ferric Chloride. World Journal of Applied Chemistry, 3, 32-40. https://doi.org/10.11648/j.wjac.20180302.11

[72] Ghernaout, D. and Boucherit, A. (2015) Review of Coagulation's Rapid Mixing for NOM Removal. Journal of Research \& Developments in Chemistry, 2015, Article ID: 926518. https://doi.org/10.5171/2015.926518

[73] Irki, S., Ghernaout, D. and Naceur, M.W. (2017) Decolourization of Methyl Orange (MO) by Electrocoagulation (EC) Using Iron Electrodes under a Magnetic Field (MF). Desalination and Water Treatment, 79, 368-377. https://doi.org/10.5004/dwt.2017.20797

[74] Ghernaout, D. (2017) Entropy in the Brownian Motion (BM) and Coagulation Background. Colloid and Surface Science, 2, 143-161.

[75] Ghernaout, D. (2018) Electrocoagulation Process: Achievements and Green Perspectives. Colloid and Surface Science, 3, 1-5. https://doi.org/10.11648/j.css.20180301.11

[76] Ghernaout, D., Simoussa, A., Alghamdi, A., Ghernaout, B., Elboughdiri, N., Mahjoubi, A., Aichouni, M. and El-Wakil, A.E.A. (2018) Combining Lime Softening with Alum Coagulation for Hard Ghrib Dam Water Conventional Treatment. International Journal of Advances in Applied Sciences, 5, 61-70. https://doi.org/10.21833/ijaas.2018.05.008

[77] Djezzar, S., Ghernaout, D., Cherifi, H., Alghamdi, A., Ghernaout, B. and Aichouni, M. (2018) Conventional, Enhanced, and Alkaline Coagulation for Hard Ghrib Dam (Algeria) Water. World Journal of Applied Chemistry, 3, 41-55. https://doi.org/10.11648/j.wjac.20180302.12

[78] Irki, S., Ghernaout, D., Naceur, M.W., Alghamdi, A. and Aichouni, M. (2018) Decolorization of Methyl Orange (MO) by Electrocoagulation (EC) Using Iron Electrodes under a Magnetic Field (MF). II. Effect of Connection Mode. World Journal of Applied Chemistry, 3, 56-64. https://doi.org/10.11648/j.wjac.20180302.13

[79] Irki, S., Ghernaout, D., Naceur, M.W., Alghamdi, A. and Aichouni, M. (2018) Decolorizing Methyl Orange by Fe-Electrocoagulation Process-A Mechanistic Insight. International Journal of Environmental Chemistry, 2, 18-28. https://doi.org/10.11648/j.ijec.20180201.14

[80] Ghernaout, D., Touahmia, M. and Aichouni, M. (2019) Disinfecting Water: Electrocoagulation as an Efficient Process. Applied Engineering, 3, 1-12.

[81] Ghernaout, D., Alghamdi, A. and Ghernaout, B. (2019) Electrocoagulation Process: A Mechanistic Review at the Dawn of Its Modeling. Journal of Environmental Science and Allied Research, 2, 51-67. https://doi.org/10.29199/2637-7063/ESAR-201019

[82] Kellali, Y. and Ghernaout, D. (2019) Physicochemical and Algal Study of Three Dams (Algeria) and Removal of Microalgae by Enhanced Coagulation. Applied Engineering, 3, 56-64.

[83] Ghernaout, D. (2019) Electrocoagulation and Electrooxidation for Disinfecting Water: New Breakthroughs and Implied Mechanisms. Applied Engineering, 3, 125-133.

[84] Ghernaout, D. and Elboughdiri, N. (2019) Electrocoagulation Process Intensification for Disinfecting Water-A Review. Applied Engineering, 3, 140-147.

[85] Ghernaout, D. and Elboughdiri, N. (2019) Iron Electrocoagulation Process for Dis- 
infecting Water-A Review. Applied Engineering, 3, 154-158.

[86] Ghernaout, D., Elboughdiri, N., Ghareba, S. and Salih, A. (2020) Coagulation Process for Removing Algae and Algal Organic Matter-An Overview. Open Access Library Journal, 7, e6272. https://doi.org/10.4236/oalib.1106272

[87] Ghernaout, D. and Elboughdiri, N. (2020) An Insight in Electrocoagulation Process through Current Density Distribution (CDD). Open Access Library Journal, 7, e6142.

[88] Ghernaout, D. and Elboughdiri, N. (2020) Eliminating Cyanobacteria and Controlling Algal Organic Matter-Short Notes. Open Access Library Journal, 7, e6252. https://doi.org/10.4236/oalib.1106252

[89] Ghernaout, D., Elboughdiri, N., Ghareba, S. and Salih, A. (2020) Disinfecting Water with the Carbon Fiber-Based Flow-Through Electrode System (FES): Towards Axial Dispersion and Velocity Profile. Open Access Library Journal, 7, e6238. https://doi.org/10.4236/oalib.1106238

[90] Ghernaout, D. (2008) Élimination des substances humiques et des germes indicateurs de contamination bactériologique par électrocoagulation assistée d'un traitement magnétique de l'eau. PhD Thesis, University of Blida, Algeria.

[91] Ghernaout, D., Elboughdiri, N., Ghareba, S. and Salih, A. (2020) Electrochemical Advanced Oxidation Processes (EAOPs) for Disinfecting Water-Fresh Perspectives. Open Access Library Journal, 7, e6257. https://doi.org/10.4236/oalib.1106257

[92] Ghernaout, D. and El-Wakil, A. (2017) Requiring Reverse Osmosis Membranes Modifications-An Overview. American Journal of Chemical Engineering, 5, 81-88. https://doi.org/10.11648/j.ajche.20170504.15

[93] Ghernaout, D. (2017) Reverse Osmosis Process Membranes Modeling-A Historical Overview. Journal of Civil, Construction and Environmental Engineering, 2, 112-122.

[94] Ghernaout, D., El-Wakil, A., Alghamdi, A., Elboughdiri, N. and Mahjoubi, A. (2018) Membrane Post-Synthesis Modifications and How It Came about. International Journal of Advances in Applied Sciences, 5, 60-64. https://doi.org/10.21833/ijaas.2018.02.010

[95] Ghernaout, D., Alshammari, Y., Alghamdi, A., Aichouni, M., Touahmia, M. and Ait Messaoudene, N. (2018) Water Reuse: Extenuating Membrane Fouling in Membrane Processes. International Journal of Environmental Chemistry, 2, 1-12. https://doi.org/10.11648/j.ajche.20180602.12

[96] Ghernaout, D. and Elboughdiri, N. (2020) Domestic Wastewater Treatment: Difficulties and Reasons, and Prospective Solutions-China as an Example. Open Access Library Journal, 7, e6141.

[97] Ghernaout, D., Elboughdiri, N. and Ghareba, S. (2020) Fenton Technology for Wastewater Treatment: Dares and Trends. Open Access Library Journal, 7, e6045. https://doi.org/10.4236/oalib.1106045

[98] Ghernaout, D. and Ghernaout, B. (2012) Sweep Flocculation as a Second Form of Charge Neutralisation-A Review. Desalination and Water Treatment, 44, 15-28. https://doi.org/10.1080/19443994.2012.691699

[99] Ghernaout, D. and Elboughdiri, N. (2020) Magnetic Field Application: An Underappreciated Outstanding Technology. Open Access Library Journal, 7, e6000.

[100] Ghernaout, D. and Elboughdiri, N. (2020) Electrochemical Technology for Wastewater Treatment: Dares and Trends. Open Access Library Journal, 7, e6020.

[101] Ghernaout, D. and Elboughdiri, N. (2019) Water Reuse: Emerging Contaminants 
Elimination-Progress and Trends. Open Access Library Journal, 6, e5981.

[102] Ghernaout, D., Elboughdiri, N. and Alghamdi, A. (2019) Direct Potable Reuse: The Singapore NEWater Project as a Role Model. Open Access Library Journal, 6, e5980. https://doi.org/10.4236/oalib.1105980

[103] Ghernaout, D. and Elboughdiri, N. (2019) Upgrading Wastewater Treatment Plant to Obtain Drinking Water. Open Access Library Journal, 6, e5959. https://doi.org/10.4236/oalib.1105959

[104] Ghernaout, D., Elboughdiri, N. and Ghareba, S. (2019) Drinking Water Reuse: One-Step Closer to Overpassing the "Yuck Factor". Open Access Library Journal, 6, e5895. https://doi.org/10.4236/oalib.1105895

[105] Ghernaout, D., Elboughdiri, N. and Al Arni, S. (2019) Water Reuse (WR): Dares, Restrictions, and Trends. Applied Engineering, 3, 159-170.

[106] Ghernaout, D. (2019) Brine Recycling: Towards Membrane Processes as the Best Available Technology. Applied Engineering, 3, 71-84.

[107] Ghernaout, D. (2019) Reviviscence of Biological Wastewater Treatment-A Review. Applied Engineering, 3, 46-55.

[108] Ghernaout, D. (2019) Aeration Process for Removing Radon from Drinking Water-A Review. Applied Engineering, 3, 32-45.

[109] Al Arni, S., Amous, J. and Ghernaout, D. (2019) On the Perspective of Applying of a New Method for Wastewater Treatment Technology: Modification of the Third Traditional Stage with Two Units, One by Cultivating Microalgae and Another by Solar Vaporization. International Journal of Environmental Sciences \& Natural Resources, 16, 555934. https://doi.org/10.19080/IJESNR.2019.16.555934

[110] Ghernaout, D., Alshammari, Y. and Alghamdi, A. (2018) Improving Energetically Operational Procedures in Wastewater Treatment Plants. International Journal of Advances in Applied Sciences, 5, 64-72. https://doi.org/10.21833/ijaas.2018.09.010

[111] Ghernaout, D., Aichouni, M. and Alghamdi, A. (2018) Overlapping ISO/IEC 17025:2017 into Big Data: A Review and Perspectives. International Journal of Science and Qualitative Analysis, 4, 83-92.

[112] Ghernaout, D., Aichouni, M. and Touahmia, M. (2019) Mechanistic Insight into Disinfection by Electrocoagulation-A Review. Desalination and Water Treatment, 141, 68-81. https://doi.org/10.5004/dwt.2019.23457 